\title{
JENIS-JENIS ORGANISME DASAR (Benthos) DI PERAIRAN SUNGAI MUSI SUMATERA SELATAN
}

\author{
Syamsul Bahri*) \\ ${ }^{*}$ Teknisi Litkayasa pada Balai Riset Perikanan Perairan Umum, Palembang
}

\section{PENDAHULUAN}

Sungai merupakan salah satu tipe ekosistem perairan umum yang mempunyai peranan penting bagi kehidupan organisme dasar (benthos) dan juga bagi kebutuhan hidup manusia. Sungai Musi merupakan sungai yang terpanjang di propinsi Sumatera Selatan. Sungai ini bermuara di Selat Bangka dekat Desa Sungsang Kabupaten Banyuasin Propinsi Sumatera Selatan.

Di perairan Sungai Musi banyak terdapat industri-industri, perkebunan, dan pemukiman penduduk. Dengan banyaknya aktivitas penggunaan lahan di tepian Sungai Musi tersebut langsung ataupun tidak langsung dapat memberikan dampak negatif terhadap mutu air sungai, mengakibatkan rusaknya ekosistem perairan, dan berdampak pula terhadap kehidupan organisme dasar (benthos) baik secara kualitas maupun kuantitas.

Organisme dasar (benthos) yang hidup di dasar perairan sungai merupakan sumber makanan utama bagi jenis-jenis ikan pemakan benthos. Karena peranannya itu maka pendugaan produksi ikan di sungai dapat ditentukan dengan melihat seberapa besar kelimpahan organisme yang ada didasar perairan tersebut (Welcome, 1985).

Tujuan pengamatan ini untuk mengetahui keragaman organisme dasar (benthos) di perairan umum Sungai Musi pada musim hujan dan musim kemarau.

\section{BAHAN DAN ALAT}

Bahan: 1) ekman drege, 2) ember plastik, 3) kantong plastik, 4) formalin $4 \%$, 5) karet gelang, 6) spidol, 7) ballpoint, 8) note book, 9) saringan bentos, dan 10) mikroskop.

Pengambilan sampel dilakukan di Sungai Musi bagian hulu, tengah, dan hilir pada bulan Juni, Juli 2002 mewakili musim kemarau dan bulan September, November 2002 mewakili musim penghujan. Letak stasiun sampling ditentukan berdasarkan pertimbangan topografi dan pemanfaatan lahan oleh berbagai aktivitas manusia. Stasiun pengamatan berjumlah 15 lokasi mewakili Sungai Musi bagian hulu, tengah, dan hilir.

Pengambilan sampel benthos dilakukan dengan menggunakan alat Ekman Drege, sampel yang didapat berupa lumpur yang bercampur organisme dasar perairan. Untuk pengamatan organisme dasar dilakukan dengan metode penyaringan dengan size ukuran yang berbeda-beda, mulai dari ukuran yang besar sampai pada ukuran yang kecil.

Organisme dasar hasil penyaringan dikumpulkan dalam botol Vial diawetkan dengan larutan formalin $4 \%$ dibawa ke laboratorium dan diidentifikasi menurut petunjuk buku Pennak (1978). Jumlah individu yang diperoleh dilakukan dengan menghitung kepadatan per $\mathrm{m}^{2}$ dengan dasar luasan Ekman Drege.

\section{HASIL PEMBAHASAN}

Jenis organisme dasar perairan Sungai Musi yang berhasil didapatkan pada waktu survei dan telah diidentifikasi tertera pada Tabel 1 (data musim kemarau) dan Tabel 2 (data musim hujan). Pada musim kemarau (Juni 2002) ditemukan 7 kelompok organisme dasar 
yaitu: kelompok insekta terdiri dari Coleopteral (2 jenis), Diptera (2 jenis), Ephemeroptera (3 jenis), dan Plecoptera (1 jenis), kelompok kedua yaitu Gastropoda ada (2) jenis, Crustacea (1 jenis), Annelida, dan Nematoda masing-masing satu jenis yang tidak teridentifikasi generanya. Pada musim kemarau (Juli 2002) ditemukan 5 kelompok organisme dasar yaitu: Crustacea (2 jenis), Insekta. (terdiri atas Diptera 2 jenis), Ephemeroptera 3 jenis, Plecoptera 3 jenis), Gastropoda (1 jenis), Nematoda (2 jenis), dan Pelecypoda ( 2 jenis).

Dilihat dari keadaan individu per $\mathrm{m}^{2}$ dan distribusinya (Tabel 1) maka tampak bahwa

Tabel 1. Kepadatan individu organisme dasar per $\mathrm{m}^{2}$ di perairan Sungai Musi pada musim kemarau tahun 2002

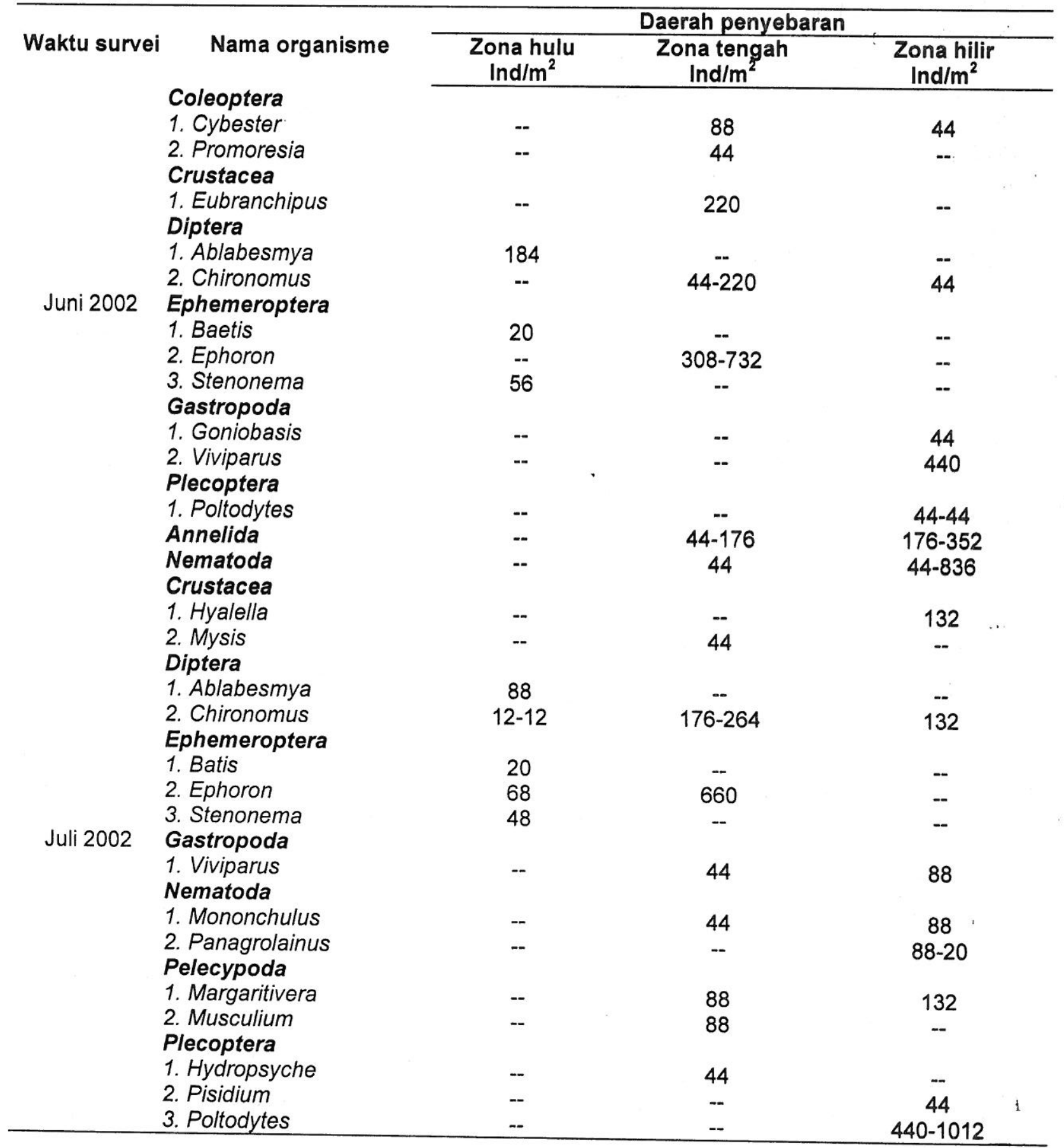


Tabel 2. Kepadatan individu organisme dasar per $\mathrm{m}^{2}$ di perairan Sungai Musi pada musim hujan tahun 2002

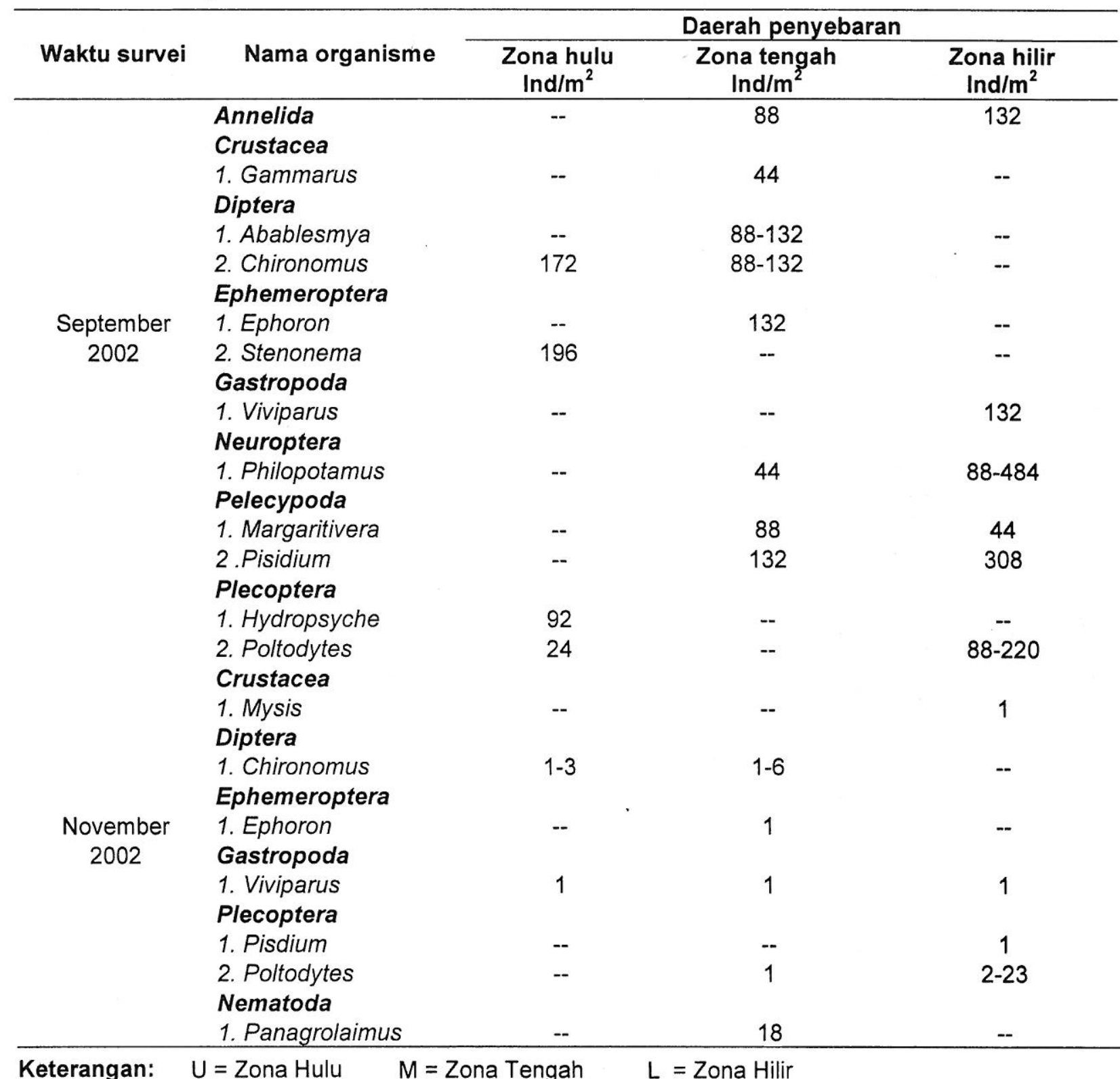

organisme dasar di perairan Musi banyak terdapat pada zona tengah dan zona hilir. Demikian pula pada musim hujan (Tabel 2) organisme dasar banyak tersebar di zona tengah dan hilir.

\section{PENUTUP}

Berdasarkan pengamatan parameter biologi, kelimpahan organisme dasar (benthos) di perairan Sungai Musi tergolong sedikit, jumlah individu per $\mathrm{m}^{2}$ lebih banyak ditemukan pada zona tengah dan hilir.

\section{DAFTAR PUSTAKA}

Pennak, R.W. 1978. Freshwater invertebrate in the United State of America. Mc. Grawhill Book Company, New York. 803 p.

Welcome, R.L. 1985. River fisheries. F.A.O. Fish. Tech. Paper (262), Rome. 330p. 